\title{
RE-WRITING THE HISTORY OF TUDOR \\ POLITICS AND GOVERNMENT: \\ THE REGIMES OF SOMERSET AND \\ NORTHUMBERLAND
}

\author{
BY DALE HOAK \\ Professor Hoak is a member of the history department \\ at the College of William and Mary
}

$\mathrm{F}$ OR sheer drama, few periods in English history can compare with the shock-ridden reign of Edward VI (I547-I 553). Inflation, war, rebellion, plague, famine, political scandal-national calamities of every sort, it seemed, visited England in these years, disasters punctuated, as it were, by the ultimate tragedy of the king's premature death ( 6 July 1553). At fifteen, three years before his majority, this bright lad, whose portraits picture him so jauntily daggered and plumed, died hairless and pitiful, the nearly comatose victim of tuberculosis and colds. The boy's end was all the more poignant since in life this Renaissance prince, so full of promise and learning, gave only his name to a reign: in fact he was a crowned puppet, his kingly authority divided among the members of a band of avaricious courtiers who, in their quest to dominate him and his powers of patronage, predictably fell out, their hatreds and jealousies erupting publicly in treasons and state trials.

At the center of this struggle for power and authority stood the two great personalities of the age, Edward Seymour, duke of Somerset, and John Dudley, earl of Warwick and (after I 55I) duke of Northumberland. For six and a half years these two successively governed England, acting essentially as de facto kings. As England's designated Lord Protector, Somerset survived at the top until October I 549 when his office was abolished in a coup d'état directed in part by Northumberland, a man so obsessed by the threat of Somerset's subsequent opposition that he was driven finally to arrange for Somerset's execution (January 1552). One year later, Northumberland himself was beheaded for his villainous attempt to bar Mary Tudor from the succession to the throne.

Not surprisingly, this fascinating and deadly struggle introduced into Tudor historiography some colorful accounts of how politics at Edward's court had been brought to such a tumultuous end. In every version, the 
accusing finger points to Northumberland, a soldier whose misplaced virtì seems to type him the Renaissance gangster par excellence. Though wrongly believed to have poisoned Edward VI, Northumberland's transparent scheme to make his daughter-in-law, Jane, queen of England, branded him thereafter the English "Machiavel." Given his other actions, this posthumous title has conveniently allowed a reputation to explain an otherwise baffling tale of political intrigue and manoeuvring apparently more Byzantine than Tudor. Internecine plots, and more than one coup-soon all of it became the work of a very wicked duke. Since an obvious, "fatal taint of crooked self-seeking" had driven him to such measures, ${ }^{1}$ there was little need to look for deeper historical explanations. Indeed, the reputation originally fixed upon him by his enemies lives on: in unison the textbooks continue to execrate him.

For historians of the period, the existence of the damned also implied a kingdom of the elect; an evil duke required that a good duke be found. A. F. Pollard discovered him in 1900 and in England Under Protector Somerset elaborated the story of a liberal reformer actually loved by the masses of Englishmen. Pollard's Somerset was perhaps too Victorian to be true. Nevertheless, we know that Somerset himself wanted to go down in history as the people's champion, and it is a fact that the epithet "good duke" was pinned on him during his own lifetime in consequence of "his opinion to be good to the poor." Moreover, Somerset enjoyed his greatest popular acclaim at the very moment of his wrongful execution on trumped-up charges of treason and felony, charges the evidence for which Northumberland confessed to have fabricated himself.

Somerset's last hour thus began to serve two legends. Northumberland had permanently stained his hands with his great rival's blood and in so doing had obviously forfeited all rights to historical respectability, even before his wild last gamble on Jane. By contrast, Somerset on Tower Hill began to look better and better, less the arrogant, dilatory, incompetent governor cited by some, more the idealist destroyed by an infamy, a great-hearted man cut down before he could really act upon his alleged concern for the poor. Even before Pollard's book, the verdict was in on what recently has been called a reign of "weak and divided rule": let Somerset rest a martyr to visionary reform; accept the executioner's axe in judgment of Northumberland's wrongs.

For more than sixty years such views dominated the accounts of poli-

\footnotetext{
1 The phrase is R. B. Wernham's, Before the Armada: the Growth of English Foreign Policy ${ }_{1485^{-1}} 5^{88}$ (London, 1966 ), 193.
} 
tics under Edward VI. Moreover, professional neglect of Edwardian political topics allowed such interpretations to obscure some fundamental questions. How, one wondered, did the two dukes of legend actually govern the realm? How did they really use the machinery of government? How, to be more specific, did they supervise the king's courts of law; manage the king's finances; control the king's council?

A reassessment of sorts began in I 966 with the publication of Professor W. K. Jordan's edition of The Chronicle and Political Papers of King $E d w a r d V I$, and continued with the appearance of the same author's two volumes entitled Edward VI: The Young King (London, I968) and Edward VI: The Threshold of Power (London, 1970). As Jordan's subtitles put it, the first volume treated The Protectorship of the Duke of Somerset and the second catalogued The Dominance of the Duke of Northumberland. In his preface to The Young King, Jordan pronounced himself "unashamed" of the "probably old-fashioned quality" of his lifeand-times approach, confident perhaps that he would impress his known critics with his industry if not his results. The industry is clearly evident in footnotes which point the way to neglected or little-used sources. On matters political, the narrative re-states Pollard's conclusions. There is little analysis of the institutions of central government; what there is often cannot be trusted. Most readers probably will remember Jordan for his portrait of the boy-king, the conception of an administrative genius and enlightened reformer who in the last eighteen months of his reign stood on the "threshold of power."

Two of the king's men have been the subject of recent biographies. Barrett L. Beer's Northumberland (Kent, Ohio, I973) is the first booklength account of John Dudley's political career. ${ }^{2}$ Surprisingly, Beer all but ignores council politics, the true arena of Northumberland's political activities in Edward's reign. S. R. Gammon's biography of William, first Lord Paget (Newton Abbot, I973), though an unrevised version of an out-dated dissertation (Princeton University, r953), nevertheless makes accessible some essential data about the Statesman and Schemer that Paget was. On the important political problems, Gammon does not disagree with Pollard's interpretations.

The true revision of the history of politics and government under Edward VI began in December 1975 with the appearance of Michael Bush's The Government Policy of Protector Somerset (London and

2 Philip Lindsay's The Queenmaker. A Portrait of John Dudley . . 1502-1553 (London, I95 I) is not scholarly. 
Montreal), a book effectively dismantling Pollard's and Jordan's views on the subject comprehended by Bush's title. Bush argues that Somerset did not possess that "liberal" outlook of legend; considering both circumstance and governmental requirements, he finds the Protector to have been a fairly unremarkable politician whose political conceptions and government policy essentially reflected the conservatism of his class.

How far has Dr. Bush advanced our understanding of Somerset's conduct of government? The question is pointedly relevant to an evaluation of Bush's work, for the author has deliberately set himself the task of constructing "a new framework for the study of politics"s during the Protectorate. What is this "new framework?" Essentially, it is the framework within which Paget analyzed the Protector's government policy in 1 549; at the time, Paget was Somerset's chief adviser. Like Paget (whose letter-book setting forth this analysis Gammon discovered), ${ }^{4}$ Bush sees Scotland as the source of Somerset's ruin; it was Paget who first perceived that Somerset's domestic difficulties proceeded directly from his fateful decision to invade and occupy Scotland. No doubt Bush is on the right track in organizing his discussion of Somerset's policy in terms of the topics that describe the government's areas of action (Scotland, "social reform," "peasant risings," the Church, etc.), action frequently taken in response to the consequences, financial and otherwise, of the duke's war policy. But, as I shall argue below, such an approach does not provide answers to some fundamental political questions of the age. Why, for example, was Somerset overthrown in 1549 , toppled not merely by Northumberland, but by the united opposition of eighteen of the twenty-one members of the king's council, a council which Somerset (as Protector) had appointed? On Bush's terms, policy alone cannot explain the coup d'état of October I 549 since, as Bush himself says, the men who dumped Somerset then had always backed the government's policy vis-a-vis Scotland. As convincing as some of his revisions are, Bush's thesis does not really tell us why the good duke's administration failed.

The reason that neither Bush's "new framework" nor the recent biographies can explain this is that they almost invariably consider politics and policy apart from institutions; none of them analyzes politics from

\footnotetext{
${ }^{3}$ Bush, op. cit., vii.

4 The letter-book is in the Northamptonshire Record Office, Fitzwilliam (Milton) MS. C. $2 \mathrm{I}$. It has been published in The Letters of William, Lord Paget of Beaudesert, 1547 $6_{3}$, ed. B. L. Beer and S. M. Jack, Camden Miscellany, xxv [Camden Fourth Series, vol. I3] (London, 1974), I-I4 I.
} 
the point of view of contemporaries who self-consciously wielded power through offices with designated (or sometimes ill-defined) functions; who chose to adhere to, modify or ignore the recognized procedures of such offices and institutions. Both Somerset and Northumberland, for example, were privy councillors-an obvious fact; less obvious is the fact that as Protector, Somerset was technically empowered to ignore the members of the council in governing the realm. ${ }^{5}$ Similarly, Northumberland, while in power, served as President of the board, an office allowing him to act effectively as a Protector in council. What one wants to know is what the two dukes understood the extent of their authority to be. How did they actually discharge their considerable powers of office? Until recently, nobody had bothered to ask such questions-Beer's book does not even mention the fact that Northumberland was Presidentand yet unless one can describe how Somerset and Northumberland viewed their institutional responsibilities one cannot successfully describe the true nature of policy-making or political action under them. What was the place of the king's council during the Protectorate? How did Northumberland act as Lord President?

The significance of this inquiry can only be understood in the context of the Tudor monarchy's special definition of government by council. The sixteenth century marked the accelerated attempts of princes everywhere to rationalize and extend their authority, to identify their personal, prerogative powers with the sovereign claims of (what we now call) the emerging territorial state. Administratively, this effort required that European kings develop centralized, "bureaucratic" machinery capable of executing their will at the "national" level. Among the many bureaucratic agencies so developed, royal councils of one type or another were nominally the most important; among royal councils generally in the sixteenth century the Tudor council was unique in respect of both the nature and scope of its authority. Thus, whereas the Valois kings of France possessed at court several councils, variously named, variously instituted (with often overlapping powers), and variously staffed (often by court favorites holding little more than the title to the office), ${ }^{8}$ Henry VIII employed in England but one board staffed by professionals and peers alike who, according to the terms of their peculiar oath, served their sovereign lord as policy-makers, administrators and quasi-judicial officials. By sixteenth-century standards, Henry's council represented a most

${ }^{5}$ See note 16 below.

${ }^{6}$ Cf. R. Doucet, Les Institutions de la France au XVI Siècle (Paris, I 948), i, 131-1 52. 
unusual body, unusual constitutionally because of its astonishingly broad competence, unusual administratively because its members could (and did) act personally to enforce the king's decisions of state.

Such a singularly unique instrument of royal government was, however, unknown in England before 1536. About that time, and certainly not later than August I 540, the Crown, or rather the Crown's chief minister, Thomas Cromwell, reformed the traditional, medieval king's council, a large, loosely organized, informally managed body, making of it a distinctively smaller, tightly-knit, formally established "privy" council.? (The word itself was used purposefully: only the post-I 536 council is properly called the privy council.) This reform constituted one aspect of what Professor Elton has described as a revolution in $\mathrm{Tu}-$ dor government: in dismantling Rome's ecclesiastical jurisdiction, Henry necessarily redefined the nature of his own authority in England; this redefinition required a more closely managed kingdom; the new privy council was designed to administer this kingdom. ${ }^{8}$ In serving the king's insistent, exclusive, "national" demands-money and obedience were the most important-the Henrician privy council assumed unprecedented powers, powers born of the secular requirements of a Reformation begun by the state.

Of course the existence of such a council presumed the existence of a capable adult sovereign. Knowing that the accession of a minor would pose extraordinary political and administrative problems, Henry VIII established before his death that during his son's minority full royal authority in England would rest equally in the hands of the sixteen executors of the old king's last will and testament. These executors were to be the only members of the new king's privy council. ${ }^{\circ}$ If the Henrician council had acquired an unusual competence to govern England, it may be said that Edward's council represented something of a revolutionary experiment in government-by-council, inasmuch as his councillors were accorded the full powers of kingship. It is this fact that makes our first question so important: in practice, what was the place of the privy council under the Protector?

Dr. Bush and everyone else before him have assumed that Somerset's policies were the product of a like-minded council, that Somerset ruled through a board whose members regularly assisted him in formulating

\footnotetext{
${ }^{7}$ Cf. Elton, The Tudor Revolution in Government (Cambridge, 1953), 316-369.

${ }^{8} \mathrm{Cf}$. Elton, England Under the Tudors (London, 1974), I60-192.

9 The will is printed in T. Rymer (ed.), Foedera, Conventiones, Litterae . . . (London, 1704-1 735), xv, I 10-11 7 .
} 
policy and governing the realm. But this is not so. A systematic analysis of the privy council register covering the period of the Protectorate has revealed that that book does not invariably record the minutes of council meetings or even the products of council business. ${ }^{10}$ What it and other sources show is that after about January I 548 Somerset abandoned the council; he dispatched state business in his own household, through his household staff, ignoring the king's secretaries and clerks of the privy council. ${ }^{11}$ Only his brother's alleged treason and the twin crises of war with France and domestic unrest forced him in 549 to reconvene a nearly defunct council, and only in order to have a group of now maddened councillors rubber-stamp his already formed decisions on matters of policy. ${ }^{12}$ It is pretty clear that the Protector's policies were his alone. ${ }^{13}$ Now, in I 547, when the council had agreed to Somerset's elevation as Protector, the members of the board thought that they would be consulted on matters of state policy. ${ }^{14}$ After January I548 (at the latest) they were not being consulted, and so they understandably resented sharing responsibility for a mismanaged realm whose Protector officially put it about that he ruled with their advice and consent. Somerset's refusal to heed their advice ran counter to their political sensibilities. When he openly dismissed their considered opinions in council they reacted by throwing him out of office.

After the coup d'état the king's councillors charged that in ignoring them, Somerset had effectively violated the terms of the secret agreement of January 1547 by which they had ratified his preferment to high office. ${ }^{15}$ They were correct. But in I 549, as victors and not the vanquished, they conveniently ignored the fact that by the terms of Somerset's letterspatent of the Protectorate (dated I 2 March I 547), the Protector of the realm was legally empowered to consult the king's councillors at his pleasure, or (as his patent reads) "... to ... use ... suche and so many

${ }^{10}$ D. E. Hoak, The King's Council in the Reign of Edward VI (London and New York, 1976), 15-23.

${ }^{11}$ Cf. Paget's letters to Somerset in Paget's letter-book, op. cit.; Hoak, op. cit., ror102, II 5-II 7.

${ }_{12}$ In a letter of 11 October 1549, explaining the coup d'état to English ambassadors abroad, the privy council stated that Somerset dispatched state business "by himself alone without calling for any of vs of the councell many tymes therunto and if for the name sake he called any man he odred the maters as pleased himself refusing to here any mans reason but his own"; Public Record Office, London, SP 10/9/fos. 72-81.

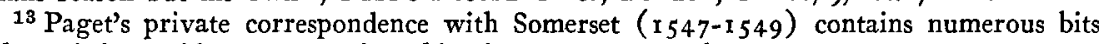
of unwitting evidence supporting this view; see note 4 above.

${ }^{14}$ Public Record Office, London, SP Io/9/fos. 72-8I, the council's letter of 1 I October I 549 to English ambassadors abroad.

${ }^{15}$ Ibid. 
[of them] as he from tyme to tyme shall thincke convenient."16 Thus, Somerset's virtual abandonment of the council, though politically unwise, was not constitutionally improper.

Of course we also know that Somerset was personally incapable of cooperating with his colleagues. By all accounts he was an ambitious, obnoxious, abrasive, arrogant grandee, much given to rebuking gentlemen to their faces. His quick-tempered outbursts, and what Paget called his "great choleric fashions," "17 reduced good men to tears. He was an autocrat whose imperious pretensions and titular flamboyance ("by the grace of God") sparked envy and hurt in those around him. His insensitivity to the opinions of others sometimes bred a burning sense of righteous vengeance in those who, like his brother, merely hungered for power, or, like Northumberland, knew themselves to be better able to govern men. In fact, as Protector of the realm, Somerset was incompetent: his inability to handle the king's men and the king's money explains why, in a crisis, he was rightly replaced. His was essentially an administrative failure marked chiefly by his unwillingness to employ the king's privy councillors to formulate and execute state policy, privy councillors who were by this time members of an institution of recognized competence.

For Northumberland (then earl of Warwick), the lesson of Somerset's failure was clear: he must somehow rule through the council, a council technically possessed of full authority - this is what Henry VIII's will had established-but a council that could be managed and controlled from within to suit his own political purposes. Politically, his chief purpose was to exercise much the same power that Somerset had held. But he was cleverer than Somerset: he knew that he could not rule alone, and certainly not with a clique of non-conciliar confidants (such as Somerset's so-called "new council" of historically anonymous men). With the help of the Archbishop of Canterbury (Thomas Cranmer), the one man (in October 1 549) most able to influence the king, Northumberland began to pack the council with hand-picked supporters. ${ }^{18}$ Following this

${ }^{16}$ Acts of the Privy Council of England, ed. J. R. Dasent (London, I890-1907), ii, 70-7I.

${ }^{17}$ Paget to Somerset, 8 May 1549, Northamptonshire Record Office, Fitzwilliam (Milton) MS. C. $2 \mathrm{x}$.

${ }_{18}$ The story is contained in the British Library, Additional MS. 48126 , fo. I 5 b. The entire document is entitled, "Certayne brife notes of the controversy betwene the dukes of Somerset and the duke of Norhumberland [sic]. . . ." The "Notes" were set down after 1561 , probably by a former clerk in Somerset's household; whatever the author's identity, it seems clear that he was present on many of the occasions recounted. Cf. A.J.A. Malkiewicz, English Historical Review, Lxx (1955), 600-609. 
political triumph, he discovered a constitutional device allowing him to conquer the council procedurally from within and so bend it to his will. This device was the office of Lord President of the council.

Thanks to Sir Julius Caesar's researches, ${ }^{19}$ we know now that the President of the Tudor privy council acted as the king's "lieutenant" in the council chamber: he was able to fix times of meetings, summon members to meetings and dissolve meetings. Most importantly, the President presided at meetings, which in practice meant that through the principal secretaries of state he controlled the agendas and so really controlled all business of state. Since traditionally, the office automatically fell to the Great Master of the king's household, Warwick perceived that the path to power in council ran literally through the royal apartments. On the eve of the council's coup against Somerset, William Paulet, Lord St. John, occupied the Great Mastership. As President of the council during the Protectorate, St. John apparently had held little more than the title to the office, since at the board the authority of the Protector really overrode that of the President. After the coup d'état, St. John relinquished the Great Mastership and the Presidency, accepting in turn both an earldom and the office of High Treasurer of England, prizes almost certainly promised to him in December I 549 when he leaked to Warwick the interesting news that the earls of Arundel and Southampton were plotting Warwick's death. ${ }^{20}$ Armed with this information, Warwick rallied his forces and (again with Cranmer's probable assistance) persuaded the king to grant him the offices of Great Master and President.

Sir Julius also discovered that an early Tudor President technically could disbar councillors at will; ${ }^{21}$ Warwick had discovered this too, for on the day of his appointment ( 2 February 1550 ), ${ }^{22}$ his first act as President was to order the earls of Arundel and Southampton banished from court and council. ${ }^{23}$ Since October 1549 , Warwick had been waiting to acquire enough influence to isolate these two opponents. By February

${ }^{19}$ British Library, Lansdowne MS. I 6o, fos. $264-267$.

${ }^{20}$ British Library, Additional MS. 48126, fo. $15 \mathrm{~b}$.

21 British Library, Lansdowne MS. 160, fo. $264 \mathrm{~b}$.

${ }^{22}$ Edward VI probably made the appointment orally on 2 February 1550 ; the king's letters-patent granting Dudley the office are dated 20 February i $55^{\circ}$; British Library, Cotton MS. Caligula E. iv, fo. 206; Calendar of the Patent Rolls, Edward VI (London, 1924-26), iii, 189-190; Charles Wriothesley, $A$ Chronicle of England during the Reigns of the Tudors from A.D. ${ }^{4} 85$ to 1559 (London, 1887), ii, 32-33; G. E. Cokayne, The Complete Peerage of England, Scotland, Ireland, Great Britain, and the United Kingdom (new ed. by V. Gibbs, London, 1910-19), ii, App. D, 622; F. M. Powicke and E. B. Fryde (eds.), Handbook of British Chronology (2nd ed., London, 196r), 1 36.

${ }^{23}$ Wriothesley, Chronicle, ii, 32-33. 
I 550 he possessed such influence, masked as it was by the Lord President's procedural powers. Although Caesar recorded his observations about the Presidency in 1617 , the evidence for the period $1550-1553$ corroborates his later assessment. We do not yet know in what manner the two earlier Presidents (the duke of Suffolk, I 540-1 543, and St. John, I 543-I 547) may have discharged their duties. It is likely that the Elizabethan and early-Stuart practice described by Caesar rested in fact on precedents set by Northumberland under Edward VI. Whatever the case, there can be no doubt that Dudley understood the potential importance of the office of a President during a royal minority: in governing England through a reformed board of councillors, it is evident that he exploited the President's powers to the full. ${ }^{24}$

The point of this discussion is simply to say that the history of Northumberland's regime, no matter how one interprets the duke's personality, makes little sense unless one looks at him as Lord President of the privy council. In doing so, one may abandon Professor Jordan's notion that under Northumberland, Edward VI stood on the "threshold of power." In fact, the king's so-called "agendas" of council meetings, his alleged reforms, even his famous speeches in council-all had been written out and performed for him in advance by a secretarial and household staff working directly from the Lord President's instructions. The king's state papers and utterances give evidence that Edward VI was merely following state business in council, not originating it. His was merely the appearance of originality and rule, not the guiding hand of a presumed genius. ${ }^{25}$ Such at least is the view of one who has sought to understand the institutional basis of political behavior at the court of Henry VIII's short-lived successor.

${ }^{24}$ For the evidence of Northumberland's control as President, see Hoak, King's Council, 105-106, 108-110, 125-129, 140-144, I54-155, 164, 313 (note 65).

${ }^{25}$ Edward VI's so-called "agendas" and notes of council business are simply copies of his secretaries' papers of similarly noted business. Compare, for example, the fourth item of Edward's "agenda" of January 1552 with the identical item on Cecil's memorandum of September 1551: British Library, Cotton MS. Vespasian F. xiii, fo. 273 and Public Record Office, SP 10/13/fo. 98. For the explanation of the king's famous speeches in council, see the eye-witness account by an anonymous resident member of the French embassy who was close to Northumberland at the time (1551-1553): Bibliothèque

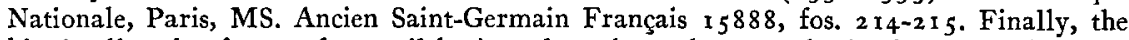
king's alleged reforms of council business have been shown to be irrelevant to the story of the reorganization of the council's work during his reign: Hoak, King's Council, 9I-I64. For additional evidence of Northumberland's manipulation of the boy, see the Calendar of Letters, Despatches, and State Papers, relating to the negotiations between England and Spain ..., ed. R. Tyler (London, I912-16), x, 437-438. 